\title{
Sounding the Media
}

\author{
An Interdisciplinary Review and Research Agenda \\ for Digital Sound Studies
}

\author{
Klaus Bruhn Jensen
}

\begin{abstract}
Sound remains significantly underresearched as a form of communication, as a modality of experience, and as a resource for cultural expression and social action. This article provides an overview of the several disciplinary and interdisciplinary sources of contemporary sound studies. As a point of departure, the article identifies and contextualizes three prototypes of sound - speech, music, and environmental soundscapes - with reference to previous work in linguistics, musicology, history, and other fields of study. A wide range of contributions are reviewed with particular reference to their explanatory value concerning different types of sound media. The article distinguishes between three degrees of media, enabling communication in the flesh, mechanically or electronically reproduced communication, and digitally mediated communication. In each case, sound can serve as a vehicle of information, as a mode of communication, and as a means of action. The article outlines a conceptual matrix, integrating the sound prototypes, the media forms, as well as the social uses of sound, with a view to further research. Finally, some specific issues on the agenda of current sound studies are discussed.
\end{abstract}

Key Words: sound, communication theory, digitalization, linguistics, musicology, soundscape.

\section{Introduction}

Sound is a constitutive part of diverse forms of communication in contemporary society - from the early-morning alarm clock, followed by the voices of our beloved, by online and offline conversations with colleagues, and by music throughout the day on stationary as well as portable players, to the late-night entertainments of surround-sound stereo, tv sets, and computer terminals. During the 1990s, three historical prototypes of sound - speech, music, and environmental soundscapes - underwent important transformations. Speech became almost omnipresent via mobile phones; music became separated from previous analog technologies and corporate infrastructures through the intervention of Napster and related developments; and soundscapes became an increasingly manifest component of computer interfaces, from Windows overtures to the personalized signals of handheld devices. The 2000s have been witnessing a further emphatic and differentiated reliance on digital sound formats, for example, the coming 
of internet telephony (VoIP), the growth of multimedia online gaming and virtual worlds, and the early stages of pervasive computing. And yet, sound remains significantly underresearched as a form of communication, as a modality of experience, and as a resource for cultural expression and social action, even if recent years have witnessed a revitalized interest internationally in the area (for overviews, see Bull \& Back, 2003; Leeuwen, 1999; Truax, 2001).

This article presents a review of several bodies of theory and empirical evidence from different research traditions that have examined sound, exploring their combined potential for advancing an interdisciplinary research agenda particularly regarding studies of digital sound. Digitalization, which is changing the very conditions for the production, distribution, as well as the uses of sound by individuals, organizations, and whole societies, provides a unique opportunity for rediscovering and reexamining the place of sound in culture and society. Computers have been sound media for some time; it is time for research to sound computers.

Because sound studies have no natural home in the academy, no full-scale equivalent of disciplines such as art history and film theory, addressing still and moving images respectively, any review will offer a selective recombination of findings and insights. The present review, while recognizing the contributions of, for example, psychoacoustics (e.g., Plomp, 2002) and audio engineering (e.g., Alten, 2002), focuses on sound as communication - as a source of meaning and as a resource for action in social and cultural contexts. The first section below revisits previous work on the three sound prototypes noted above - speech, music, and environmental soundscapes. Whereas much of this work is anchored in disciplines such as linguistics and musicology, a number of contributions have fallen either outside or between disciplines or, as in the case of musicology, they have challenged the discipline from within. The following section locates digital sound within the wider field of sound studies, outlining three technological degrees of sound media, their distinctive features, and their interrelations. Next, the sound prototypes and the three degrees of media are joined in a matrix which serves to identify a range of issues for empirical and theoretical research. The final section structures and discusses these issues as part of a research agenda that covers sound as a vehicle of information, as a mode of address in communication, and as a means of action both at the interface and in the social contexts embedding media and their users. In conclusion, the paper raises a meta-issue of research, suggesting that the current interest in sound studies itself may be the product of a reconfigured media environment in which sound has come back in style.

\section{Three Fields of Sound Studies}

\section{Speech: from Classical Rhetoric to Modern Discourse Studies}

'In the beginning was the Word, and the Word was with humans, and the Word was humans.' A secular restatement of the New Testament (John 1:1-3) serves to articulate the modern understanding that speech or symbolic communication is constitutive of being human. Language, along with abstract thinking and self-awareness, is commonly considered among the minimal conditions for civilized social interaction (Megarry, 1995: 48). One distinctive feature of language is that it enables reflection and negotiation before individuals, organizations, or whole societies take action. Language supports not just great leaps of the imagination and grand collective projects, but, perhaps most important, doubt and delay. As noted by Aristotle (Clarke, 1990: 11), 
words allow humans to consider that which is at least temporarily absent - in space, in time, and from one's immediate experience - through thought experiments and dialogue. Speech, thus, can represent what is absent from, but imagined within, face-to-face encounters, opening up universes of what is not yet, what might be, as well as what ought never to come to pass. Present sounds allow for absent realities.

Writing, print, electronic, and digital media, each in specific ways, radically extended the capacity of humans to imagine, represent, and communicate, also in each other's absence. Present media allow for absent realities, absent communicators, or both. Information and communication technologies - from the alphabet to the computer provided one necessary condition for the historical development of complex social systems across time and space, and for the massive human transformation of the natural environment (for reviews of 'medium theory' research, see Deibert, 1997; Meyrowitz, 1994). Not surprisingly, the relative determination of society by technology, and vice versa, has remained subject to intense research debate (for key positions, see Biagioli, 1999). Comparatively less attention has been paid to the continued and constitutive functions of speech within and around technologically mediated communication (for exceptions, see, e.g., Gumpert \& Cathcart, 1986; Scannell, 1991). Also before and beyond media and communication research, scholarship traditionally has subordinated speech as a communicative practice to language as a formal structure.

Rhetoric, being the grandparent of language study, drew on the resources and conventions of oral tradition while developing as a social practice as well as a field of research (for a history of rhetoric, see Kennedy, 1980). Yet, paradoxically, 'classical' rhetoric was being codified and consolidated as part of a transition to literate culture. Havelock (1963), for one, noted how Plato's attack on the bardic poets for being less than trustworthy in matters of government, historiography, and science, announced the passing of an oral culture. In areas as diverse as commerce, religion, warfare, and politics, writing and literacy provided strategically important means of social organization and control (see further, e.g., Goody, 1987; Goody \& Watt, 1963; Innis, 1951; 1972/ 1950; Scribner \& Cole, 1981). Rhetorical practice itself was informed and sustained by written manuals - alphabetization facilitated codification. And, it was not least in the shape of "secondary rhetoric" (Kennedy, 1980: 5), as applied to diverse genres of literary and other written communication, that rhetorical concepts continued as a major influence on European scholarship and education into the nineteenth century. Poised between oral practice and literate form, rhetoric has remained a source of inspiration for communication theory up to and including 'mass media' studies.

The plethora of practical manuals on the art of speaking well in public help to account for the still common reference to 'only rhetoric' - form without substance. It might be more appropriate, in fact, to refer to 'only literacy' - texts without context, as memorized and delivered on cue. Classical rhetoric had emphasized the intimate relation between knowing that something is the case, and knowing how to speak about it for a purpose and in a context. Aristotle observed that rhetoric is the source of a particular kind of knowledge which is probable and reasonable in relation to the business at hand - in comparison, logic can provide certain or necessary knowledge across contexts, at least about some aspects of reality (Clarke, 1990: 13). An important legacy of rhetoric for contemporary communication studies, then, is its close focus on context. This focus has been revitalized, for example, by the 'new rhetoric' (Perelman, 1979) and by the field of science communication studies, probing how researchers themselves articulate and legitimate their findings (e.g., Brodkey, 1987; Gilbert \& Mulkay, 1984; Simon, 
1989). As speech and other auditory modalities of communication are being reembedded in everyday contexts through mobile technologies (J. E. Katz \& Aakhus, 2002; Ling, 2004), both 'old' and 'new' rhetorics can offer theoretical and methodological frameworks for empirical research.

The distinctive capacity of writing and, later, print to transcend context made the written word a focus of language study for centuries. As a social infrastructure and source of power, sustaining empires and cosmologies, literacy required both a canon of forms and procedures, and a class of literate individuals to maintain it, on behalf on the powers that be. Philology (see, e.g., Cerquiglini, 1999; Olender, 1992), while focused originally on classical Greek and Latin, developed a wide range of general techniques for performing textual criticism of both historical, scientific, and literary works, fact as well as fiction, in different languages. By establishing the origins and relative authenticity of diverse texts, philology served as a crucial mediator of knowledge from and about the past, recontextualizing history in the present. The essentially contestable nature of this enterprise was witnessed, for example, during the nineteenth century when philology, while acquiring a new level of precision, participated actively in political projects of nation-building. By documenting and delimiting 'national' languages and literatures, philology provided justifications for what was then a new type of imagined communities (Anderson, 1991: 67-82). Across national boundaries and social contexts, moreover, literacy became a generalized resource of cultural distinction (Bourdieu, 1984, 1988). Literacy gives access to a particular heritage, and it empowers the literate to negotiate inclusion in and exclusion from this heritage, even the appropriate language for doing so. Like money, literacy talks - it speaks of social structure in action. The different historical varieties of language study, by implication, speak of how cultural capital has been administered by scholarship on behalf of society.

Linguistics in its twentieth-century incarnation performed a reorientation, on the one hand, away from the diachronic and comparative attention of philology to language as a vehicle of history and culture. Instead, linguistics came to highlight language as a structure in its own right and in a synchronic perspective. The seminal work of Saussure (Saussure, 1959/1916) served as a key influence on other structuralist and systemic turns beyond linguistics and into the social sciences. On the other hand, twentieth-century language study did remain focused on writing in its various shapes and, for all practical purposes, on a canon of written language - on form and norm. One ambition of modern linguistics was to develop into an autonomous 'science' beyond a subordinate role of servicing literary and other 'arts' of language. That ambition was expressed most systematically by socalled transformational-generative grammar (TG), which sought to discover a 'deep structure' of language that would account for the seemingly infinite variety of its 'surface structures' in speech and writing (Chomsky, 1965). TG was informed by the widely influential notion of human cognition as computing; a metaphor that was taken literally, to varying degrees, in the borderlands of TG and AI, or artificial intelligence research (Boden, 1996). If the constituent structures of human language production and understanding can be operationalized as algorithms, then computers may conceivably model not just the form of writing, but the content of reasoning, as well. And, given appropriate multimodal facilities, computers might speak with their users. The binary alphabet, thus, could be said to reconfigure the boundary between 'writing' and 'speech' (Bolter, 1991; Finnemann, 1999). Precisely speech, however, with its sensitivity to context has posed one of the most serious obstacles so far in the development of operational AI systems (Partridge, 1991). 
In recent decades, linguistics has returned to speech as a key object of study, including the many public and private settings in which language use makes daily life possible. Under a generic heading of discourse studies, much work has addressed discourse as a social process over above texts as the products of language (for an overview, see Wetherell, Taylor, \& Yates, 2001) (for other approaches to 'discourse' as a theoretical framework, see Phillips \& Winther Jørgensen, 2002). In linguistic terminology, discourse studies go beyond the grammar, semantics, and phonetics of single, abstracted sentences, to include pragmatics, which examines the social uses of language in complex sequences and situated contexts. Several factors, internal as well as external to research, help to explain this 'pragmatic turn' (Jensen, 2002a: 38-39). Internally, linguistics joined an interdisciplinary turn across the humanities and social sciences, exploring the role of language in the micro-coordination of everyday life. In this regard, linguistics has been returning to what Saussure (1959/1916) had envisoned as an extrapolation of linguistics, namely, semiology, or a science that would study "the life of signs in society" (p. 16) (which today is more commonly referred to as semiotics (Posner, Robering, \& Sebeok, 1997-98)). To exemplify, sociolinguistics has gone beyond the documentation and comparison of 'dialects' and 'sociolects' in order to account for them as implicit worldviews and constitutive practices within the ongoing structuration of society (Giddens, 1984). The title of one classic text - "the logic of non-standard English" (Labov, 1972/1969) - indicates that, as late as 1969, it was still necessary to argue the point that, in this case, spoken Black English was more than an illogical aberration from the norm.

The external circumstances of language study, next, help to explain such a 'finding.' The anti-authoritarian upheavals during the 1960s were questioning received notions of a common cultural heritage, as well as of ethnicity, class, and gender (Harvey, 1989; Roszak, 1969). The challenges to consensus were being amplified throughout society by a new media environment in which, not least, television was transcending social boundaries (Meyrowitz, 1985). Importantly, the challenges were being posed not merely as 'issues' in media content, but equally through the forms of communication - through diverse variants of language as practiced by distinctive subcultures. The cultural diversity of language was now undeniably there to be listened to every night on the news, also by language scholars.

Over the longues durées of history, it is fair to conclude that the study of language has tended to revolve around literacy. Societies depending on writing similarly came to depend on practices for administering and maintaining the written word. The de facto 'othering' of speech and its variants is best seen as a cultural consequence of a changing social infrastructure, rather than of any grand ideological or metaphysical battle between literacy and orality, as held by much poststructuralism since Derrida (1976/1967). Like language itself, language study is conditioned by its material and institutional circumstances, including the technologies available. Before the late nineteenth century, speech disappeared into the air unless documented by hand for particular purposes (Millard, 1995; Nyre, 2003; Sterne, 2003). From the 1940-50s onwards, lightweight recording equipment made fieldwork and subsequent transcriptions of language use more feasible (Fielding \& Lee, 1998: 28). And, recent 'corpus linguistics,' working from empirical samples rather than imagined prototypes, depends on computer analysis to determine how people actually speak (and write) (Halliday, 2004).

In sum, current sound studies are positioned to benefit from previous research about language on at least two counts. First, the rhetorical tradition as well as the 
interdisciplinary field of discourse studies have offered many and diverse insights into speech as practice and process. Second, philology and linguistics have provided concrete approaches to writing both as a cultural technology and as an analytical resource, as enhanced by mechanical and digital means of reproduction. Speech - and the study of speech - is amplified through written techniques of notation, transcription, and analysis.

\section{Music: From Autonomous Works to Interested Listeners}

Form and norm have served as guiding principles for research on music, as well. For one thing, the academic study of music - musicology - arguably has been wedded less to sounds than to notes. Traditionally, the discipline has placed a strong emphasis on 'works' as formal objects, as they are represented in written scores, curating and commenting on an "imaginary museum of musical works" (Goehr, 1992). This is in spite of the fact that song and improvised performances presumably account for the majority of all musical events both historically and currently, literally accompanying people from cradle to grave (e.g., Crafts, Cavicchi, \& Keil, 1993; DeNora, 2000). For another thing, musicology has been remarkably focused on a particular portion of the notated heritage, namely, the canon of 'classical' instrumental music especially from the late 1700s onwards. (The term 'classical' music itself dates from the late 1800s (Potter, 1998: 65) and remains debated.) Although, for example, Dahlhaus (1982b/1967: 92), indicated that a canon may be understood as what is being 'chosen from,' rather than a few 'chosen' works, publications in musicology widely argue for or imply an absolutist and universalist position (e.g., J. Johnson, 2002). If literary and other aesthetic studies have cultivated the autonomy of artworks with a passion, musicology has pursued aesthetic autonomy with a vengeance.

Like rhetoric, music has been practiced as both art and scholarship since Antiquity (Treitler, 1998: 3). More so than rhetoric, musical scholarship has retained an intimate link with musical performance, as witnessed at conservatories as well as university schools of music (Kingsbury, 1988; Nettl, 1995). Scholars will normally be expected to practice music or, minimally, to be formally 'literate.' Also the published literature indicates that it is the aesthetics of musical works as means of expression and contemplation that has remained at the top of the 'research agenda' - if that is a relevant terminology (for classic texts, see Treitler, 1998) (for overview and discussion, see, e.g., Bergeron \& Bohlman, 1992; Christensen, 2002; Dahlhaus, 1982a/1967). In comparison, the broadly social uses of music in politics, religion, or primary socialization have remained on the periphery of the field as a minority concern. This is in spite of early contributions on music by some of the founding figures of sociology (Schütz, 1976a/ 1944, 1976b/1951; Weber, 1958/1921). As in the case of language study, the profile of academic musicology is explained, in part, by its infrastructural position vis-à-vis other social institutions. Musicology has served, in large measure, as the keeper of canonical tradition regarding the appropriate social uses of sound, as defined by shifting religious and secular establishments. The implicit commitment to musical performance, catering to the powers that be, has manifested itself, moreover, in particular scholarly techniques. According to Kerman (1985: 59), the meticulous, archival care for the "facts and texts" of music amounts to a variant of positivism. It is the socially interested nature of both music and musicology that a great deal of recent work has come to underscore. 
Certainly, the musicological mainstream had been supplemented and, to an extent, challenged by several other forms of inquiry during the twentieth century. Ethnomusicology, in particular, has detailed the constitutive role of music in the everyday life of diverse cultural groups and settings, including processes of identity formation and practices of religion (Born, 2000; Manuel, 1988; Nettl \& Bohlman, 1991). Like other contemporary anthropology, ethnomusicology has extended its methodologies to western musics and comparative studies, probing the cultural standing of Mozart from the viewpoint of a complete outsider or 'Martian' (Nettl, 1992) and symphony concerts as social rituals (Small, 1987). Psychology has addressed the cognitive and affective aspects especially of the reception of music, ranging from Gestalt-oriented approaches (Meyer, 1956) to cognitive models of how musical structures are generated in the mind (Lerdahl \& Jackendoff, 1983). Much of the growing body of work during the past few decades, however, has chosen a rather narrow route in its empirical studies, examining responses to brief musical segments typically within a laboratory setting (e.g., Deutsch, 1999; Hodges, 1996; Sloboda, 1985), also in the attempt to capture the crucial link of music and emotion (Juslin \& Sloboda, 2001). Semiotics, moreover, has made a bid for studying musical sounds as signs, with implications for the constitution of subjectivity and the exercise of cultural agency (Cumming, 2000; Hatten, 1994; Nattiez, 1990; Tarasti, 1994). Still, as in the case of musicology proper, semiotics has been limited by its formal analytical categories as derived, in part, from Saussurean linguistics. Music therapy, finally, has begun to document in some detail the healing powers of music, even while recognizing the difficulties of explaining the processes at work beyond the level of tacit or enacted knowledge (Bunt, 1994; Wigram, Saperston, \& West, 1995). In this regard, music therapy can be said to sum up a dilemma in much previous scholarship on music, being caught in a methodological bind between artful practice and scientific positivism.

The reassessment and reinvigoration of musicology that seem to be underway (Cook \& Everist, 1999) have been facilitated by two specific departures from the mainstream. From within, the tradition has been challenged head-on by the socalled ' $n e w$ ' or 'critical' musicology, which has brought the origins of music in, as well as its implications for, society to the fore, reemphasizing meaning, power, class, gender, and other classic concepts from the social sciences and cultural studies in the discourse of research (Kramer, 2002; Leppert, 1993; McClary, 1991, 2000; Subotnik, 1991). According to Subotnik (1991: 141), the interrelation of music and society should be treated, not as a hypothesis to be tested, but as a premise for research in the first place. While internally diverse, the New Musicology has taken a broadly critical, emphatically theoretical, and historically grounded position, drawing inspiration from a Frankfurt-School lineage of social theory, feminism, and discourse theory, in order to substantiate some of the ways in which music articulates socially interested perspectives on reality. In addition to raising controversial issues regarding musical divides between social segments, and recovering female composers and musicians that have gone unrecognized in music history (McClary, 1991), this group of researchers has also broadened the methodological scope of musicology, drawing on visual representations of music and musicians as well as other historical evidence in order to place musical texts in their social contexts (Leppert, 1993). Still, the methodologies of the New Musicology have, in practice, stayed comparatively close to the core musical 'texts,' whether notated or performed, treating other evidence as supplementary. Most important perhaps, the process of listening and employing music for social ends is still largely being extra- 
polated from the works rather than from evidence concerning the listeners themselves, despite some recent work on hearing in social and historical contexts (Erlmann, 2004). In this respect, research on music may be retracing the steps of media and, not least, film studies, which, until quite recently (e.g., Stacey, 1994), relied on an audience of one the researcher - to furnish interpretations of the media text at hand.

The second, external challenge to musicology has come from the field of popular music studies (for key texts, see Frith \& Goodwin, 1990; Middleton, 1990) (for overview, see Hesmondhalgh \& Negus, 2002; Longhurst, 1995; Shuker, 2001; Starr \& Waterman, 2003). Whereas 'popular' music might be considered both historically and ontologically primary, the term is often used as a synonym for 'not classical,' and is most commonly associated with those genres that reach a mass audience through technological reproduction. Frith (1996: 226) has suggested that one may begin to think of the history of music generally in terms of a folk stage grounded in the body, an art stage sustained by notation, and a pop stage enabled by reproduction, which have entered into shifting, remediated configurations. Addressing the ambiguous position of much contemporary popular music in between 'genuine' folk and 'commercial' pop sources, the field has produced modern classics of its own, for example, on the place of music in African-American culture (Keil, 1966) and on the emotional qualities of music in the media (Tagg, 1979). Moreover, studies of the words or texts of popular songs (Hawkins, 2002; Jones, 2002; Middleton, 2002) serve as one reminder that 'classical,' instrumental music might be considered a historical anomaly - music and speech have typically been constituents of the same cultural practice. The downside of the focus within popular music studies on subcultures and social institutions is that, frequently, less explicit attention is given to musical practices as music. Middleton (1990: 158), for one, noted a tendency for subcultural theory to rely excessively on homology to account for the relationship between musical and social structures: Rock, for instance, may qualify as 'screw and smash' music, but that description says little about its specificity as a cultural practice of sound and speech. Studies of music and society still tend to be silent on either society or music, partly because of limitations in the available theoretical and terminological repertoires.

Music follows people from cradle to grave, but not so musicology. One indication that this situation may be changing is the publication of volumes examining music and society which bring (new) musicology and popular music studies inside the same covers (Clayton, Herbert, \& Middleton, 2003; Scott, 2000). In addition to the diversity of traditions complementing and challenging mainstream musicology, recent decades have witnessed a growing number of studies in the sociology and social psychology of music (Hargreaves \& North, 1997; Martin, 1995; White, 1987), addressing questions of identity and gender (Solie, 1991; Whiteley, Bennett, \& Hawkins, 2004), of music in mobilizing social movements (Ansell, 2004; Eyerman \& Jamison, 1998; Garofalo, 1992), of early opera as a social experiment in the emotional implications of music (R. Katz, 1986), as well as of the changing historical uses of technologically mediated music (Nott, 2002). Indicating one agenda for further research, Peterson and Kern (1996) found that while the traditional divide between highbrow and lowbrow music tastes may be dissolving, it is especially highbrow listeners who have embraced popular music, as well. At an institutional level, Born (1995) showed how, over the course of the twentieth century, avantgarde 'serial' music contributed to new configurations of 'classical,' experimental, and popular music. And, in the context of everyday practices, Finnegan (1989) detailed how different conceptions of 'composition' and 'performance' enter into 
various musical subcultures or art worlds (Becker, 1982), high and low, professional and amateur. In each case, technology is changing the conditions of what will count as music, for whom, and to what social ends.

\section{Soundscapes: From Music of the Spheres to Ambient Environments}

The notion that the natural environment, indeed, the entire universe, carries meanings that are articulated, in part, through sound, is familiar from the ancient idea of the music of the spheres (James, 1995; Treitler, 1998: 102f.). The harmony of the spheres was understood as an expression of the numerical ratios of a 'world-soul,' yielding mathematical principles with implications for astronomy, metaphysics, and music, and, according to some, sounding the universe. (A contemporary parallel is 'DNA music,' generating musical syntheses from DNA sequences (Gena \& Strom, 2001).) Whereas a modern perspective would suggest a categorical distinction between natural events and human actions, and between incidental and intentional meanings, nevertheless humans habitually ascribe significance to both social and natural settings - as symbols in their own right or as arenas of action. Watzlawick et al. (1967) made the point that one cannot not communicate, noting that the presence of humans in a shared time and space necessarily implies communication: The body shows itself, and it sounds. Social contexts, similarly, cannot not communicate, at least as enabling conditions of what can or should, cannot or should not, occur there. From homes and offices, to public transportation and rural landscapes, environments are increasingly planned and engineered, thus anticipating, configuring, and contributing to meaningful interactions, including silence. Appadurai (1996) has suggested 'scapes' as a covering term for various material and simultaneously meaningful frameworks of human action. Soundscapes, while currently associated, for example, with mobile media, have taken a variety of historical forms.

The specific terminology of 'soundscapes' is normally credited to the Canadian composer and musicologist, R. Murray Schafer (1977). Recalling the medium theory (Meyrowitz, 1994) of his countrymen, Innis and McLuhan, that media typify particular epochs of culture and consciousness, Schafer interpreted the history of sound as a process of schizophonia, by which technologies have increasingly divorced sounds from their origins, thus potentially polluting both social and natural contexts, and desensitizing audiences to the potential richness of sound in work as well as leisure. One of Schafer's important contributions has been to identify sound as a general and complex modality that should be studied as a natural phenomenon, an artistic expression, as well as a mode of communication. Several international, comparative studies have built on this perspective to assess the contemporary state of soundscapes around the world (Truax, 1995) (see also Jarviluoma, 1994; Southworth, 1969). As a framework for theory development and further empirical research, however, Schafer's position is limited by its highly normative premises, in effect demonizing noise, praising silence, and implicitly advocating a return to preindustrial soundscapes (e.g., Toop, 1995: 253f.). A comparable position within communication studies, influenced by the media ecology of Postman (1985), appeared in Albrecht (2004).

Perhaps surprisingly, historians have been at the forefront of recent sound studies (Bailey, 1996), reassessing the evidence regarding past soundscapes, which, unlike textual and pictorial sources, literally disappeared into the air until the advent of recording technologies from the late 1800 s. One important contribution came from 
Corbin (1998), who explored the significance of village bells as frame-setters in the French countryside during the nineteenth century. Beyond the traditional enactment of standardized time in local communities, bells gave rise to deep social conflicts after the French revolution of 1789, involving state authorities, the church, as well as laypeople, particularly over the appropriate religious or secular uses of bells within a community. And, as part of conflicts between communities, bells were abducted, reused, and recast. In a different national setting, the recasting of bells into cannon could be seen to symbolize the predicament of the American south after the Civil War (M. M. Smith, 2001) - both the war and the sounding bells were lost. Meanwhile, trains and other noisy machines continued their westward journey, representing the industrial future of the Northern victors and a renewed challenge to the American pastoral ideal of a quiet life in the wilderness (Marx, 1964). With reference to early modern England, Smith (1999) has suggested that the growing importance of literacy for the organization of society was changing the perceived implications of sound as a mode of interaction as well as a sensory experience in oral communication. In the case of music, studies also have considered hearing in a historical perspective (Burnett, Fend, \& Gouk, 1991; Wegman, 1998), and have reemphasized the continued importance of oral tradition, both as a presence in daily life and as a concrete force in shaping the musical practices of religious and other literate institutions, for example, Gregorian chant (Jeffrey, 1992), and in framing the understanding of musical works as orations and organisms (Bonds, 1991).

In a contemporary perspective, soundscapes have increasingly been reengineered and remediated, from incidental spaces of hearing to dedicated places of listening - whether in private homes or concert halls. Forsyth (1985) charted the development of music 'auditoria,' from the first public performances in English taverns of the 1600s, to the growth of concert facilities for the growing middle classes particularly from around 1800. Thompson (2002: 7), moreover, noted how the engineering of specific contexts for listening entailed a "silencing of space," as reverberation came to be defined as noise, to be replaced by different degrees and varieties of 'virtual sound.' Also audiences fell silent, as attention became focused on the stage and its musical performances, giving rise to individual, interior experience, rather than social interaction with others in the hall (J. H. Johnson, 1995). Other public places, such as shops and restaurants, have been studied as soundscapes comprising both specific information and contextual ambience. Slow music, for instance, may induce people to stay longer and drink more in restaurants (Bruner, 1990). One distinctive component of modern urban life has been 'muzak,' establishing an ambient ground through 'mood music,' or what Lanza (1994) referred to as "elevator music," in workplaces, shops, and other enclosed soundscapes (see further Barnes, 1988) (on the history of muzak, also http://www.muzak.com, accessed June 10, 2005).

Private settings, equally, have constituted historically shifting soundscapes for families and their social circles, large or small, offering piano recitals, radio broadcasting, or home-stereo listening. With portable audio devices came additional degrees of freedom in the creation of ad hoc soundscapes, beginning with the portable gramophone at picnics and 'discos' during the 1910s (Nott, 2002: 33-43). While the transistor radio made music and other sounds more mobile from the 1960s, it still imposed a collective soundscape on its immediate surroundings - spaces of hearing rather than places of listening. The Walkman from 1979 enabled individual listeners to create a private auditory realm within the public domain. Bull (2000) has shown the multiple ways in which the Walkman enabled people to negotiate the experience of self 
vis-à-vis social reality (see also Gay, Hall, Janes, Mackay, \& Negus, 1997). And, with mobile phones, iPods, and other playback devices, portable and personalized soundscapes are proliferating in public, as well (Humphreys, 2005). 'Early' notions of immersive mediascapes during the 1980s (Levy, 1993) envisioned a form of virtual reality that would transpose a full-fledged context onto a single multi-functional text the world in a medium. Current developments in ubiquitous and pervasive computing, potentially, reverse this relation, as they embed media in diverse objects, artefacts, and settings (Lyytinen \& Yoo, 2002) - the world as a medium. Soundscapes and ubiquitous mediascapes generally are challenging received notions of what $i s$ a medium.

\section{Sounds of Three Degrees}

\section{Media of the First Degree}

The familiar dichotomy of 'mediated' and 'unmediated' communication assumes that the human body, giving off sounds and other expressions, does not qualify as a medium of contact and exchange, but somehow communicates directly. This dichotomy is, in part, a product of the first phase of 'mass communication' research, which focused on technological mediation as a necessary link between one sender and many receivers. With the rise of several more differentiated media formats - both one-to-one and manyto-many - the dichotomy is increasingly in question. At the present stage of both media history and media theory, it is helpful to distinguish conceptually and analytically between three degrees of media (Jensen, 2002b).

Media of the first degree can be defined, in preliminary terms, as the biologically based, socially formed resources that enable humans to articulate an understanding of reality, for a particular purpose, and to engage in communication about it with others. The central example is verbal language, or speech - additional examples include song and other musical expression, dance, drama, painting, and creative arts generally. Such media depend on the presence of the human body, and operate in local time-space, often relying on comparatively simple, mechanical techniques such as musical instruments and artistic or writing utensils as constitutive elements. (Handwriting presents a special case, which has supported complex historical communication systems. However, its comparatively inefficient forms of reproduction and distribution, arguably, made this a transitional cultural form (Meyrowitz, 1994: 54)).

Beyond conversations involving family and friends, neighbors and coworkers, sound is constitutive of a variety of social practices. An illuminating historical example is 'rough music' (E. P. Thompson, 1991: 467-538), or the 'naming and shaming' of people who had offended a community, which was common in eighteenth- and nineteenthcentury England, having parallels in other European countries and the US. While chanting and shouting obscenities is hardly associated with either aesthetic or social harmony, rough music recalls the variable boundary between music and noise, for example, when sounds are used to articulate a social position for oneself and to interpellate others (Attali, 1985). And, rough music is not entirely a thing of the past: On March 11, 2005, BBC World News reported that authorities in Andhra Pradesh, India, had sent groups of drummers to tax evaders' houses to make them pay up (http:/ /news.bbc.co.uk/1/hi/world/south_asia/ 4397907.stm, accessed July 4, 2005).

Several kinds of research have addressed communication in the flesh, crisscrossing the three audio prototypes reviewed above. A rare contribution on the general phenomenology and experiential qualities of sound was offered by Ihde (1976). 
Psychoacoustics has moved beyond the examination of single sounds to consider the contextual 'scenes' (Bregman, 1990) in which sound events are perceived and interpreted (Handel, 1991; McAdams \& Bigand, 1993; Plomp, 2002). Also within the arts, sound has received growing attention under headings of multimedia, intermedia, and sound art (Kahn, 1999; Shaw-Miller, 2002), partly with reference to its contribution to synaesthesia (Baron-Cohen \& Harrison, 1997; Cook, 1998; Cytowic, 1989). With further reference to sound as a resource for action as well as a source of meaning, Pittam (1994) outlined an approach to the human voice as a constitutive element of social interaction. Ostwald (1973) suggested how the sounds of one's own body - from heartbeats to humming - help to ground everyday routines. And, complementing studies in the pragmatics of language, work on kinesics and nonverbal communication has emphasized how the copresence of bodies in context helps to frame and orient their interaction (Birdwhistell, 1971; Hall, 1969, 1971). Schneider (1994) specifically explored concert singing as a bodily and kinesthetic form of expression. In a crosscultural perspective, Feld (1990) showed how sound may serve as a common denominator for the cosmology and concrete communicative practices of an entire community or culture (see further Baumann \& Fujie, 1999; Classen, 1993; Howes, 1991).

Current references to the ongoing 'mediatization' of politics and culture may obscure the fact that embodied speech, music, and other sounds remain integral to everyday life. As noted by one standard textbook of media studies (McQuail, 2005: 18), the total number of face-to-face interactions that occur within the micro-coordination of daily life by far outnumber those communicative events which are technologically mediated. Moreover, speech became an integral part of the modern mass media, notably radio and television, further stimulating audience interactions around media (Gumpert \& Cathcart, 1986; Scannell, 1991). Indeed, Ong (1982) argued that the technological reembedding of speech had produced a new form of 'secondary orality.' Speech delivers not just the contents, but also many of the forms that have been remodeled as media genres - the town crier as news announcer, the court jester as talkshow host. For digital sound studies, it is essential to consider not just the reworking of analog sound technologies, but also the human body as a source and medium of sound, in its own right and as a constituent of soundscapes.

\section{Media of the Second Degree}

Media of the second degree are Benjamin's (1977/1936) technically reproduced and enhanced forms of representation and interaction which support communication across space and time, irrespective of the presence and number of participants. Early modern examples included the standardized reproduction of religious and political texts through the printing press (Eisenstein, 1979). In radio talkshows, conversation took on new forms, just as acting styles were adapted from the theater stage to cinema and television. Thus, media technologies have performed a reembedding, both of media of the first degree and of people in relation to distant others, issues, and arenas. Over the last decade or so, several volumes have sought to stimulate research on the specificity of sound in technologically mediated communication (e.g., Altman, 1992; Cook, 1998).

Most basically, recording technologies from the late nineteenth century onwards enabled the preservation of sound events (for a historical overview, see Millard, 1995). Apart from the new possibilities of documenting social and cultural history, for instance, through oral sources (Dunaway \& Baum, 1996), not least popular music gained new 
resources of expression as well as distribution. In an early contribution on the relationship between sound and technology, Jones (1992), for example, described the recording process as a cultural practice that is accomplished jointly by audio artists and technical professionals. Negus (1992), further, pointed to the various social conflicts and ideologies of creativity that overlay the concrete process of producing pop. Chanan (1995) noted the distinctive ways in which popular and classical forms of music tend to be recorded, leaving greater scope for the 'production' and 'remixing' of popular music. And, Hennion (1997) has clarified the wide range of 'mediators' - from scores and instruments, to recordings, clubs, concert halls, and street settings - which make very different kinds of music, from baroque to rock, available to different social and cultural groups. In this perspective, recording technologies are but one constituent of the cultural infrastructure of music.

In media terms, it was sound transmission technologies that made radio the first 'mass medium' on a national scale. Within media studies, however, radio was overshadowed by television during the first decades of the field's comparatively short history, despite early studies outlining an agenda (e.g., Cantril \& Allport, 1971/1935). In addition to institutional and social histories as well as overviews (Crisell, 1994; Douglas, 1999; Hendy, 2000; Scannell \& Cardiff, 1991), recent work has begun to address the cultural implications of radio, including its aesthetic forms and everyday uses (Crisell, 2004; Hilmes \& Loviglio, 2002), its place in clashes between musical cultures (Biocca, 1990), and its specificity as an auditive medium (Aaberg, 1999). Regarding television, with few exceptions (Altman, 1986), it is only quite recently that research has come to examine, for instance, music in relation to televisual genres and flow (Negus \& Street, 2002).

Like television, film has largely been conceived as a 'visual' medium in both research and public debate. The exception is film music, which has been examined rather extensively as a constitutive feature of narration especially in the fiction film (e.g., Kalinak, 1992; Kassabian, 2001). On a more modest scale, dialogue as a means of expression and mode of address to audiences, has been the subject of some studies (Chion, 1999; Kozloff, 2000). Paradoxically, at present, silent film may be stimulating a more general and sustained focus on sound. Extending a renewed interest among film scholars in the silent era, Altman (2004) detailed how music and other sounds were part of the experience of 'cinema' from the outset, as films, popular songs, and music in combination entered into the program of various entertainments (see further Abel \& Altman, 2001). Studies of silent film sound substantiate the more general point that media are incrementally and "culturally invented" (Carroll, 1988: 143), being shaped at the intersection of new technological potentials, cultural traditions, and institutional circumstances. What started out as separate modalities, as mediated by stand-alone technologies, subsequently entered into multimodal multimedia, facilitating new forms of creativity and communication.

\section{Media of the Third Degree}

Media of the third degree are the digitally processed forms of representation and interaction which reproduce and recombine previous media on a single platform - computers can be understood as 'meta-media' (Kay \& Goldberg, 1999/1977). The central current example is the networked personal computer. This 'interface,' however, is likely to change substantially as technologies are adapted further to the human senses, and inte- 
grated into both common objects and social arrangements. A characteristic feature of media of the third degree is their (potential) multimodality, partially reenacting or simulating the qualities of interaction in the flesh. In certain respects, humans are media; in certain respects, digital media can substitute the social roles of humans.

Figure 1. Media of Three Degrees

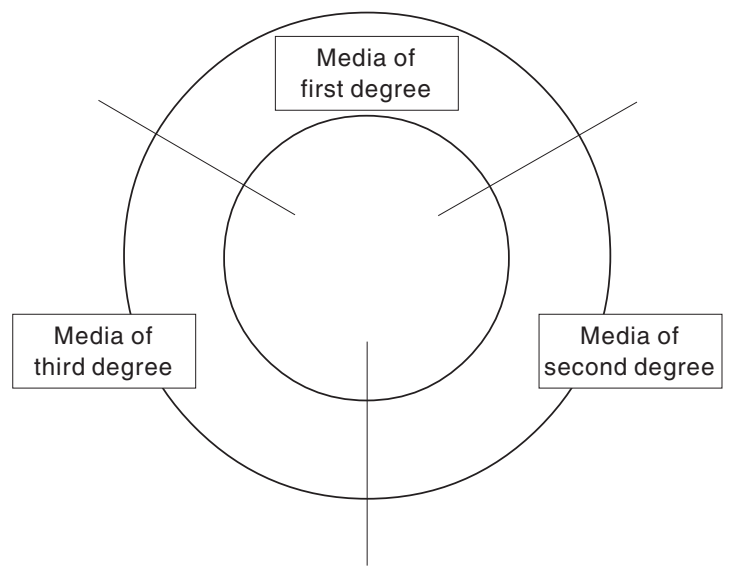

Computer networks enable forms of interaction that are more similar to interpersonal than to mass communication, as exemplified by the informality of e-mail and chat. The configuration of media of three different degrees may be understood as a wheel of culture, recirculating forms as well as contents throughout the historically available cultural technologies (Figure 1). Sound is a case in point. Through mobile phones and other portable devices, people are able to increasingly design and manage their own soundscapes, conversing with friends and family at a time and place of their choosing, and 'pulling' musical numbers to generate or relieve moods. Simultaneously, users can access entertainments and information services of the 'push' variety.

Research has begun to account for the distinctive features of media of the third degree (e.g., Gauntlett \& Horsley, 2004; Jones, 1998; Lievrouw \& Livingstone, 2002). Studies, to some extent, have considered sound as a constituent of digital media forms. For music, beyond the much publicized and controversial issue of sharing already existing files (Leyshon, Webb, French, Thrift, \& Crewe, 2005), one potential use of the internet is online collaborative music making and performances (Barbosa \& Kaltenbrunner, 2002). Sound art, more generally, has gained specific digital resources (Greene, 2003; Paul, 2003). Speech has become a more prominent component of the media environment as a whole, not least through the diffusion of cell phones and other mobile devices, with implications for both the conventions of conversation and the maintenance of social relationships (J. E. Katz \& Aakhus, 2002; Ling, 2004). Also chat in the literal sense of the word, through generally available conferencing systems such as iChat (http:// www.apple.com/macosx/features/ichat/, accessed November 24, 2005), is reintroducing speech as a constituent of online communication. And, in the case of soundscapes, computer games rely extensively on sound effects, music and, for multiplayer gaming, 
spoken interaction for coordination of the gameplay (Friberg \& Gärdenfors, 2004; Stockburger, 2003; Williams, Caplan, \& Xiong, 2005). In a wider perspective of political and cultural participation, sounds may contribute to the sensuous involvement of an interested public, as facilitated by collaborative archives (e.g., http:// freesound.iua.upf.edu/, accessed November 24, 2005). The Sonic Memorial project, for one, commemorating the events of September 11, 2001 and the sounds of the neighborhood around the World Trade Center, included functionalities in its website to enable visitors to "add a sound" (http://sonicmemorial.org, accessed March 11, 2005) (Cohen \& Willis, 2004).

Most of the work on digital sound media lies in the future. The media of three degrees provide a framework in which to approach the distinctive affordances (Gibson, 1979; Hutchby, 2001) of sound under different technological circumstances. Figure 2 gives a nine-cell matrix with examples of the kinds of communicative events and actions that enter into the field of sound studies. The final section outlines some of the issues to be addressed as part of a research agenda with particular reference to digital sound.

Figure 2. A Matrix of Sound Prototypes and Media Platforms

\begin{tabular}{|c|c|c|c|}
\hline & First degree & Second degree & Third degree \\
\hline Speech & $\begin{array}{l}\text { - Parent-child dialogue } \\
\text { - Instructions in work } \\
\text { team } \\
\text { - Parliamentary debate }\end{array}$ & $\begin{array}{l}\text { - Answering-machine } \\
\text { message } \\
\text { - Dictated medical file } \\
\text { - Royalty's broadcast } \\
\text { to citizenry }\end{array}$ & $\begin{array}{l}\text { - Coordination of } \\
\text { supermarket shop- } \\
\text { ping via mobile phone } \\
\text { - Computer-supported } \\
\text { foreign-language } \\
\text { learning } \\
\text { - Synthetic-voice } \\
\text { switchboard }\end{array}$ \\
\hline Music & $\begin{array}{l}\text { - Lullaby } \\
\text { - Work song } \\
\text { - Religious chanting }\end{array}$ & $\begin{array}{l}\text { - 'Our song' played at } \\
\text { dinner. } \\
\text { - Opera recording } \\
\text { - National anthem } \\
\text { played back at sports }\end{array}$ & $\begin{array}{l}\text { - Personalized ring } \\
\text { tone } \\
\text { - Collaborative online } \\
\text { music performance } \\
\text { - MP3 archive }\end{array}$ \\
\hline Soundscape & $\begin{array}{l}\text { - Mother's womb } \\
\text { - Fishing boat } \\
\text { - Marketplace }\end{array}$ & $\begin{array}{l}\text { - Family den } \\
\text { - Elevator } \\
\text { - Cinema hall }\end{array}$ & $\begin{array}{l}\text { - Ambient sound during } \\
\text { iChat } \\
\text { - CAVE } \\
\text { - Location-based } \\
\text { sound installation }\end{array}$ \\
\hline
\end{tabular}

\section{Towards a Research Agenda for Digital Sound Studies}

\section{Information, Communication, and Action}

One common feature of sound media is their potentially invasive quality - sounds engage anyone within hearing range. As commented by McLuhan and Fiore (1967: 112), "we simply are not equipped with earlids." The various audio modalities, moreover, are comparatively open and contextually flexible as sources of meaning. Music mostly serves non-representational, but strongly suggestive functions. In comparison, speech carries highly conventionalized meanings across contexts. And yet, the human voice incorporates many additional layers of meaning, giving away the gender, age, personality, cultural background, and emotional state of the speaker. Sounds are difficult 
to control or predict, may turn against their senders, and may get in the way of communication with others. Corner (2002), for one, noted that music tends to be used sparingly in television documentaries so as not to compromise the factual status of the narrative.

In order to capture the specificity of speech, music, and other audio modalities, as they enter into different media, it is useful to return to the basics of communication theory. Media are vehicles of information; they are channels of communication; and they serve as means of both interpersonal and macrosocial action. The conceptual pair of 'information' and 'communication,' moreover, is familiar from several fields of research. Philosophy traditionally distinguishes between proposition and modality, i.e., a potential reference and the reality status being assigned to it in an assertion (Audi, 1996: 499). In structuralist literary and film theory, enoncé refers to a work as a statement or message, whereas enonciation captures the act of enunciation (Stam, Burgoyne, \& Flitterman-Lewis, 1992: 105). And, in speech-act theory (Austin, 1962; Searle, 1969), a distinction was introduced between the locution (propositional components) and the illocution (a social act being accomplished, for example, a question or an answer). In conjunction, information and communication accomplish socially coordinated actions - from discussion and voting, to consumer purchases and investments, to cultural and aesthetic involvement. To exemplify, the internet constitutes a historically unique configuration of information and communication, being a digital marriage of a massive information archive with high-speed communications. Most important perhaps, the internet enables users to act and interact, not just with each other and at a distance, but with the system of communication in ways that may significantly reshape the very system (Finnemann, 2005) - through textual input, visual display, and sound.

- Information. Sound serves as an explicit and regularized vehicle of delimited items of information. This is the case, for instance, in oral narratives, but presumably also with fire alarms (no warning without an implied object of attention) as well as jingles and other 'program music' that seeks to generate ideas or values in the listener (Tagg \& Clarida, 2003).

- Communication. Sound facilitates intersubjective relations of communication. An oral narrative engages its listeners, young and old. A fire alarm, when activated by a person or by smoke, addresses a warning to the inhabitants of a building. And, program music produces, however tendentially and momentarily, some level of understanding and orientation in the audience.

- Action. Sound accomplishes physical as well symbolic actions, over and above the (speech) act being performed in and of communication - sound becomes action as it is embedded in established social practices and institutions. Story-telling is a classic part of primary socialization; fire alarms accomplish evacuations; and program music reactivates imagined communities (Anderson, 1991), ranging from nationalism to consumerism.

\section{Speech, Music, and Soundscapes Revisited}

The three prototypical audio modalities - speech, music, and soundscapes - enter into different configurations of information, communication, and action, raising a variety of research questions concerning the social uses of different sound media. Concerning speech, recall, to begin, the portion of Fahrenheit 471 (Bradbury, 1976/1954) where people are depicted as memorizing entire books in order to ensure that they may be 
reprinted once the present 'dark age' of banning books is over. The scenery suggests two points, namely, that language remains an eminently flexible resource for articulating human experience as information, but also that speech is exceedingly vulnerable as a medium for storing and communicating such information to others. Media of the third degree can be said to have given oral communication a new lease on life. Beyond the Fahrenheit universe, not just bound books, but audio books, online voice chat, and offline conversation may survive as history, depending on the archiving practices of national and international institutions. Speech accomplishes a multitude of everyday actions, from public speech acts of naming or passing sentences, to the most intimate of family conversations. Societies are being spoken every day.

Music, as noted, is generally not considered a vehicle of information so that, in philosophical terminology, music may have sense, but no reference. In Langer's (1957: 240) terminology, music consists of "unconsummated symbols," to be consummated by listeners. In context, however, music is readily consummated as information, being associated with product brands or political ideologies. Furthermore, music indirectly refers to and identifies an aesthetic heritage for trained listeners, effectively reaffirming their social identity and cultural capital (Bourdieu, 1984). Being able to distinguish a composition by Bach from one by Händel is as much a representation of the listener as of the music. (In the case of speech, similarly, the identity of 'mother' and other familiar voices is recognized through their grain (Barthes, 1977/1972) - in semiotic terminology, sound can be understood as an 'iterative index,' whose reference is communicated and maintained over time.) Music also acts - for example, as signals denoting transitions to, from, and within social ceremonies, or by generating an ambience for what should, or should not, happen in a given context, from the discotheque to the funeral parlor. Music performs the basso continuo, as it were, of a great deal of social interaction.

Soundscapes, while being composites of sound, may be analyzed on a par with media and their component parts. On the one hand, the various sounds constituting a soundscape can be natural events, customized signals, musical sequences, verbal utterances, etc. As such, one or more sounds might be interpreted as 'texts' or responded to as cues for orientation and involvement. On the other hand, soundscapes provide a grounding of diverse activities in context - social 'figures' against an auditive 'ground.' Short of a neat and discrete set of audio modalities, sound studies will benefit from analyses which recognize this dual status. Soundscapes make up aggregated sets of information, communicating to listeners and anticipating their likely range of activities. In literary terms, soundscapes amount to a horizon of expectations (Jauss, 1982). In the philosophical terms of Wittgenstein (1958), listeners, while having no explicit interpretation of the soundscape as such, may nevertheless know "how to go on" (No. 154).

Also the distinctions between audio modalities within soundscapes, finally, call for analytical attention - when is a voice speaking, and when is it singing, with what implications for listeners? And, given the potential for technological mediation and modification, the status of sounds is called into question - is that my cell phone ringing or a sound effect on my radio? Chion (1994) identified three ways of listening to and interpreting sounds. First, listening can be 'causal,' responding to sounds as the effects of events or actions that call for alertness. Second, sounds can be approached in terms of their semantics, as carriers of a coded message, typically verbal language. Third, people listen to sound as sound, what Chion called 'reduced listening,' notably when treating sound as an aesthetic phenomenon. Although each mode of listening might be associated particularly with one sound prototypes (reduced listening to music, semantic 
listening to speech, causal listening to soundscapes), sound studies need to explore their interrelations in empirical research on audiences. Moving beyond the traditional emphasis of musicology on reduced listening, as performed expertly by musicians and musicologists, it is essential to ask to what extent and in which ways listeners practice this cultural ideal. Complementing the focus of linguistics on semantics, it is important to examine how reduced listening to the quality of voices, and causal listening to the implied social structure of turn-taking within a group, may enter into everyday interaction, technologically mediated or not. Also in practical terms of designing and developing, for example, multimodal internet search engines, a key challenge is to be able to typologize and operationalize both audio and other modalities.

\section{Sound Media Remediated}

This review has suggested how a given medium will reproduce, reconfigure, and remediate the modalities of previous media forms. In their volume on the process of remediation, Bolter and Grusin (1999) emphasized that, in the present terminology, 'mass' media of the second degree are being reshaped within 'new' media of the third degree. Sound media serve as one reminder that also 'embodied' media of the first degree need to be reconsidered in theory development concerning the media constituting contemporary culture. Extending the perspective of Bolter and Grusin (1999), further research may explore at least three varieties of remediation (see further Jensen \& Helles, in press):

- Recycling. Taking websites as a familiar illustration, a key component of sites from diverse areas of social life is material which has previously appeared in other media, or which simulates their genre conventions. Typical examples include the sounds and images of radio and television news, advertising, and self-presentations by business companies and civic organizations, sometimes in the form of media subsections - an online organizational 'newspaper,' 'radio station,' or 'television station.' Politicalparty and parliamentary sites, for example, feature national anthems. And, personal homepages commonly include popular music items as a way of articulating the owner's identity while simultaneously positioning users.

- Redifferentiation. Studies of the web and the internet as such have variously advocated and criticized the notion of 'convergence' (Gordon, 2003), that many, most, or even all media are becoming integrated in technological, institutional, and perhaps sociocultural respects. The concept of redifferentiation seeks to acknowledge a complex process of convergence as well as divergence across media of all three degrees. On the one hand, digitalization and interrelated communication protocols potentially join previously separate kinds of mass-mediated, organizational, and interpersonal interaction. On the other hand, their concrete configuration on a digital platform gives rise to highly differentiated social uses. Again with reference to websites, both company magazines ('mass' print medium) and children's stories ('interpersonal' interaction) are read aloud at some sites; videos of the kind commonly found in malls and supermarkets ('how to cook with our products') reappear at websites; and personal homepages invite users to engage in karaoke.

- Reverberation. The term 'reverberation' is introduced here to capture traditionally oral forms, ranging from personal interchanges to religious and poetic expressions, which are finding new outlets in digital media, from websites to cell phones. This can 
be thought of, tentatively, as a form of 'tertiary orality,' extrapolating from Ong's (1982) notion of the secondary orality of electronic media. The sound of the human voice literally reverberates speakers' bodies and listeners without earlids, carrying connotations of authenticity and, perhaps, a transcendental reality. In the context of websites, blessings and prayers are downloadable from religious organizations, whereas hymns and national anthems at parliamentary and party sites invite citizens to align themselves with particular social collectives.

Whereas the perspective of remediation directs attention toward the different material and institutional platforms on which 'information' is presented, additional research questions concern the specificity of sound as 'communication.' For websites, Jensen and Helles (in press) identified three levels in the communicative uses of sound. At a first level, sound is 'in your face' as a direct mode of address - speech hails a visitor to a website, or music frames the interaction being initiated. Such pushing of sound may be used rather sparingly and specifically, as noted, given the personally invasive and culturally controversial status of sound. At a second level, sound effects or soundscapes will alert and orient users to transitions and choices to be made within the flow of interaction with the medium. At a third and final level, once media users enter and remain within a subsection of a website, a television narrative, or a music video on a portable device, they make themselves available to a multimodal complex of text, video, as well as audio. One might think of a modified version of the WYSIWYG principle ('what you see is what you get') of graphic user interfaces, underlying the three levels of sound: 'what you hear' is, as a rule, a consequence of what you selectively pull from 'what you see.'

Figure 3. Dimensions of a Research Agenda for Sound Studies

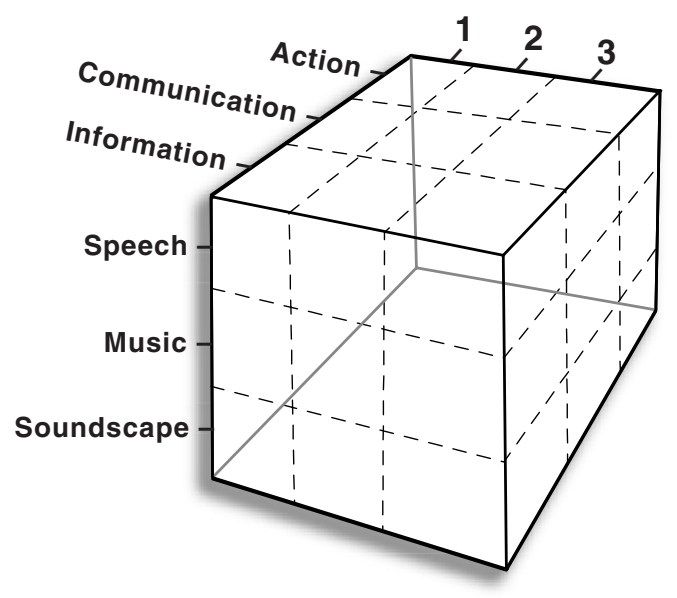

\section{Conclusion}

Sound studies are still in their early stages, and have much to gain from an extraordinarily broad range of disciplinary and interdisciplinary sources. This review has recovered a great deal of previous research on three prototypes of sound - speech, music, and soundscapes - for media and communication research. The analysis of theory and em- 
pirical findings has suggested that digital media provide a special opportunity to reexamine both the expressive qualities and the social uses of sound across media of the first, second, as well as third degrees - from bodies speaking and singing, to avatars responding in kind. Digitalization has brought sound and its diverse uses as information, communication, and action to the fore once again. Figure 3 summarizes the dimensions of a research agenda for future sound studies with reference to the three sound prototypes, the three media degrees, and the status of sound as information, communication, and action.

As shown by Peters (1999) in his history of the idea of communication, the available technologies and institutions of communication help to explain how researchers as well as the general public, over time, have thought of different media and modalities. The coming of mass communication, during the nineteenth century, served to thematize 'communication' as a general human practice, joining face-to-face and technologically mediated communication in a common vocabulary. During the post-1945 period, another general category of 'media' emerged, as epitomized by McLuhan (1964). His reference, however, was primarily to 'mass' media, even if the changing conditions of interpersonal communication in the global village were duly noted. Indeed, the record of communication research as a whole still shows the existence of a great divide between two separate worlds of 'interpersonal' and 'mediated' communication studies (Rogers, 1999). It is only within the last decade or so that students of the media have come to to refer to themselves in terms of 'media and communication' research, as symbolized by the IAMCR, which used to be the International Association for Mass Communication Reseach, but which, since 1996, is the International Association for Media and Communication Research. The field is currently working out the implications of that seemingly innocent change of terminology.

Perhaps communication researchers are still catching up with the general idea of communication. Perhaps media researchers are still in need of a general definition of media. Sound studies are a good place to continue the search for both media and communication.

\section{References}

Aaberg, C. (1999). The Sounds of Radio: On Radio as an Auditive Means of Communication. Stockholm, Sweden: Stockholm University.

Abel, R., \& Altman, R. (Eds.). (2001). The Sounds of Early Cinema. Bloomington: Indiana University Press.

Albrecht, R. (2004). Mediating the Muse: A Communications Approach to Media, Music, and Cultural Change. Creskill, NJ: Hampton Press.

Alten, S. R. (2002). Audio in Media (6th ed.). Belmont, CA: Wadsworth.

Altman, R. (1986). Television/Sound. In T. Modleski (Ed.), Studies in Entertainment. Bloomington: Indiana University Press.

Altman, R. (2004). Silent Film Sound. New York: Columbia University Press.

\section{Acknowledgments}

An earlier version of this article, entitled "Sounds of Three Degrees: The Interdisciplinary Sources of Sound Studies," was presented as a paper at the 17th Nordic Conference for Media and Communication Research, Aalborg, Denmark, August 11-14, 2005. The author is grateful to the organizer of the Working Group on Radio and Other Sound Media, Lars Nyre, and other participants for their contributions to the discussion. Special thanks are due to Michael Bull, Rasmus Helles, and Steve Jones, who offered constructive comments on the conference paper. 
Altman, R. (Ed.). (1992). Sound Theory / Sound Practice. New York: Routledge.

Anderson, B. (1991). Imagined Communities: Reflections on the Origin and Spread of Nationalism (2nd ed.). London: Verso.

Ansell, G. (2004). Soweto Blues: Jazz, Popular Music, and Politics in South Africa. New York: Continuum.

Appadurai, A. (1996). Modernity at Large: Cultural Dimensions of Globalization. Minneapolis: University of Minnesota Press.

Attali, J. (1985). Noise: The Political Economy of Music. Minneapolis: University of Minnesota Press.

Audi, R. (Ed.). (1996). The Cambridge Dictionary of Philosophy (Reprinted ed.). Cambridge: Cambridge University Press.

Austin, J. L. (1962). How to Do Things with Words. Oxford: Oxford University Press.

Bailey, P. (1996). Breaking the Sound Barrier: A Historian Listens to Noise. Body \& Society, 2(2), 49-66.

Barbosa, A., \& Kaltenbrunner, M. (2002). Public Sound Objects: A Shared Musical Space on the Web. Paper presented at the Second International Conference on WEB Delivering of Music (WEDELMUSIC'02).

Barnes, S. H. (1988). Muzak. The Hidden Messages in Music: A Social Psychology of Culture. Lewiston, NY: The Edwin Mellen Press.

Baron-Cohen, S., \& Harrison, J. E. (Eds.). (1997). Synaesthesia: Classic and Contemporary Readings. Oxford: Blackwell.

Barthes, R. (1977). The Grain of the Voice. In R. Barthes (Ed.), Image, Music, Text (pp. 179-189). London: Fontana. (Orig. publ. 1972).

Baumann, M. P., \& Fujie, L. (Eds.). (1999). Special Issue: Hearing and Listening in Cultural Contexts (Vol. 41(1)): The World of Music.

Becker, H. (1982). Art Worlds. Berkeley, CA: University of California Press.

Benjamin, W. (1977). The Work of Art in the Age of Mechanical Reproduction. In J. Curran, M. Gurevitch \& J. Woollacott (Eds.), Mass Communication and Society. London: Edward Arnold. (Orig. publ. 1936).

Bergeron, K., \& Bohlman, P. V. (Eds.). (1992). Disciplining Music: Musicology and Its Canons. Chicago: University of Chicago Press.

Biagioli, M. (Ed.). (1999). The Science Studies Reader. New York: Routledge.

Biocca, F. (1990). Media and Perceptual Shifts: Early Radio and the Clash of Musical Cultures. Journal of Popular Culture, 24(2), 1-15.

Birdwhistell, R. L. (1971). Kinesics and Context: Essays on Body-Motion Communication. London: Penguin.

Boden, M. A. (Ed.). (1996). Artifical Intelligence. San Diego, CA: Academic Press.

Bolter, J. D. (1991). Writing Space: The Computer, Hypertext, and the History of Writing. Hillsdale, NJ: Lawrence Erlbaum.

Bolter, J. D., \& Grusin, R. (1999). Remediation: Understanding New Media. Cambridge, MA: MIT Press.

Bonds, M. E. (1991). Wordless Rhetoric: Musical Form and the Metaphor of Oration. Cambridge, MA: Harvard University Press.

Born, G. (1995). Rationalizing Culture: IRCAM, Boulez, and the Institutionalization of the Musical Avantgarde. Berkeley, CA: University of California Press.

Born, G. (Ed.). (2000). Western Music and Its Others: Difference, Representation, and Appropriation in Music. Berkeley, CA: University of California Press.

Bourdieu, P. (1984). Distinction. Cambridge, MA: Harvard University Press. (Orig. publ. 1979).

Bourdieu, P. (1988). Homo Academicus. Stanford: Stanford University Press.

Bradbury, R. (1976). Fahrenheit 451. London: Granada. (Orig. publ. 1954).

Bregman, A. S. (1990). Auditory Scene Analysis: The Perceptual Organization of Sound. Cambridge, MA: MIT Press.

Brodkey, L. (1987). Academic Writing as Social Practice. Philadelphia, PA: Temple University Press.

Bull, M. (2000). Sounding Out the City: Personal Stereos and the Management of Everyday Life. Oxford: Berg.

Bull, M., \& Back, L. (Eds.). (2003). The Auditory Culture Reader. Oxford: Berg.

Bunt, L. (1994). Music Therapy: An Art Beyond Words. London: Routledge.

Burnett, C., Fend, M., \& Gouk, P. (Eds.). (1991). The Second Sense: Studies in Hearing and Musical Judgment from Antiquity to the Seventeenth Century. London: Warburg Institute.

Cantril, H., \& Allport, G. W. (1971). The Psychology of Radio. New York: Arno Press. (Orig. publ. 1935).

Carroll, N. (1988). Mystifying Movies: Fads and Fallacies in Contemporary Film Theory. New York: Columbia University Press.

Cerquiglini, B. (1999). In Praise of the Variant: A Critical History of Philology. London: The Johns Hopkins University Press. 
Chanan, M. (1995). Repeated Takes: A Short History of Recording and Its Effects on Music. London: Verso. Chion, M. (1994). Audio-Vision: Sound on Screen. New York: Columbia University Press.

Chion, M. (1999). The Voice in Cinema. New York: Columbia University Press.

Chomsky, N. (1965). Aspects of the Theory of Syntax. Cambridge, MA: MIT Press.

Christensen, T. (Ed.). (2002). The Cambridge History of Music Theory. Cambridge: Cambridge University Press.

Clarke, D. S. (1990). Sources of Semiotic. Carbondale, IL: Southern Illinois University Press.

Classen, C. (1993). Worlds of Sense: Exploring the Senses in History and Across Cultures. London: Routledge.

Clayton, M., Herbert, T., \& Middleton, R. (Eds.). (2003). The Cultural Study of Music: A Critical Introduction. London: Routledge.

Cohen, E. L., \& Willis, C. (2004). One Nation under Radio: Digital and Public Memory after September 11. New Media \& Society, 6(5), 591-610.

Cook, N. (1998). Analyzing Musical Multimedia. Oxford: Oxford University Press.

Cook, N., \& Everist, M. (Eds.). (1999). Rethinking Music. Oxford: Oxford University Press.

Corbin, A. (1998). Village Bells: Sound and Meaning in the 19th-Century French Countryside. New York: Columbia University Press.

Corner, J. (2002). Sounds Real: Music and Documentary. Popular Music, 21(3), 357-366.

Crafts, S. D., Cavicchi, D., \& Keil, C. (1993). My Music. Hanover, NH: Wesleyan University Press.

Crisell, A. (1994). Understanding Radio (2nd ed.). London: Routledge.

Crisell, A. (Ed.). (2004). More than a Music Box: Radio Cultures and Communities in a Multi-Media World. New York: Berghahn.

Cumming, N. (2000). The Sonic Self: Musical Subjectivity and Signification. Bloomington: Indiana University Press.

Cytowic, R. E. (1989). Synaesthesia: A Union of the Senses. New York: Springer.

Dahlhaus, C. (1982a). Esthetics of Music. Cambridge: Cambridge University Press. (Orig. publ. 1967).

Dahlhaus, C. (1982b). Foundations of Music History. Cambridge: Cambridge University Press. (Orig. publ. 1967).

Deibert, R. J. (1997). Parchment, Printing, and Hypermedia: Communication in World Order Transformation. New York: Columbia University Press.

DeNora, T. (2000). Music in Everyday Life. Cambridge: Cambridge University Press.

Derrida, J. (1976). Of Grammatology. Baltimore, MD: Johns Hopkins University Press. (Orig. publ. 1967).

Deutsch, D. (Ed.). (1999). The Psychology of Music. New York: Academic Press.

Douglas, S. J. (1999). Listening In: Radio and the American Imagination. Minneapolis: University of Minnesota Press.

Dunaway, D. K., \& Baum, W. K. (Eds.). (1996). Oral History: An Interdisciplinary Anthology (2nd ed.). Walnut Creek, CA: Alta Mira Press.

Eisenstein, E. L. (1979). The Printing Press as an Agent of Change: Communication and Cultural Transformation in Early-Modern Europe. Cambridge: Cambridge University Press.

Erlmann, V. (Ed.). (2004). Hearing Cultures: Essays on Sound, Listening, and Modernity. Oxford: Berg.

Eyerman, R., \& Jamison, A. (1998). Music and Social Movements: Mobilizing Traditions in the Twentieth Century. Cambridge: Cambridge University Press.

Feld, S. (1990). Sound and Sentiment: Birds, Weeping, Poetics, and Song in Kaluli Expression (2nd ed.). Philadelphia, PA: University of Pennsylvania Press.

Fielding, N. G., \& Lee, R. M. (1998). Computer Analysis and Qualitative Research. London: Sage.

Finnegan, R. (1989). The Hidden Musicians: Music-Making in an English Town. Cambridge: Cambridge University Press.

Finnemann, N. O. (1999). Thought, Sign, and Machine: The Computer Reconsidered. Retrieved December 15, 1999, from http://www.hum.au.dk/ckulturf/DOCS/PUB/nof/TSM

Finnemann, N. O. (2005). The Cultural Grammar of the Internet. In K. B. Jensen (Ed.), Interface://Culture - The World Wide Web as Political Resource and Aesthetic Form. Copenhagen: Forlaget Samfundslitteratur/NORDICOM.

Forsyth, M. (1985). Buildings for Music: The Architect, the Musician, and the Listener from the Seventeenth Century to the Present Day. Cambridge: Cambridge University Press.

Friberg, J., \& Gärdenfors, D. (2004). Audio Games: New Perspectives on Game Audio. Paper presented at the ACE04: Advances in Computer Entertainment Technology Conference, Singapore.

Frith, S. (1996). Performing Rites: On the Value of Popular Music. Oxford: Oxford University Press.

Frith, S., \& Goodwin, A. (Eds.). (1990). On Record. London and New York: Routledge.

Garofalo, R. (Ed.). (1992). Rockin' the Boat: Mass Music and Mass Movements. Boston, MA: South End Press. 
Gauntlett, D., \& Horsley, R. (Eds.). (2004). Web.Studies (2nd ed.). London: Edward Arnold.

Gay, P. d., Hall, S., Janes, L., Mackay, H., \& Negus, K. (1997). Doing Cultural Studies: The Story of the Sony Walkman. London: Sage.

Gena, P., \& Strom, C. (2001). A Physiological Approach to DNA Music. Paper presented at the 4th Computers in Art and Design Education Conference, Glasgow.

Gibson, J. J. (1979). The Ecological Approach to Perception. London: Houghton-Mifflin.

Giddens, A. (1984). The Constitution of Society. Berkeley, CA: University of California Press.

Gilbert, G. N., \& Mulkay, M. (1984). Opening Pandora's Box: A Sociological Analysis of Scientists' Discourse. Cambridge: Cambridge University Press.

Goehr, L. (1992). The Imaginary Museum of Musical Works: An Essay in the Philosophy of Music. Oxford: Clarendon.

Goody, J. (1987). The Interface between the Written and the Oral. Cambridge: Cambridge University Press.

Goody, J., \& Watt, I. (1963). The Consequences of Literacy. Comparative Studies in Society and History, 5 , 304-345.

Gordon, R. (2003). Convergence Defined. Retrieved October 24, 2005, from http://www.ojr.org/ojr/business/1068686368.php

Greene, R. (2003). Internet Art. London: Thames \& Hudson.

Gumpert, G., \& Cathcart, R. (Eds.). (1986). Inter/Media: Interpersonal Communication in a Media World. New York: Oxford University Press.

Hall, E. T. (1969). The Hidden Dimension. Garden City, NY: Anchor.

Hall, E. T. (1971). The Silent Language. Garden City, NY: Anchor.

Halliday, M. A. K. (2004). Lexicology and Corpus Linguistics: An Introduction. London: Continuum.

Handel, S. (1991). Listening: An Introduction to the Perception of Auditory Events. Cambridge, MA: MIT Press.

Hargreaves, D. J., \& North, A. C. (Eds.). (1997). The Social Psychology of Music. Oxford: Oxford University Press.

Harvey, D. (1989). The Condition of Postmodernity. Oxford: Blackwell.

Hatten, R. S. (1994). Musical Meaning in Beethoven: Markedness, Correlation, and Interpretation. Bloomington, IN: Indiana University Press.

Havelock, E. A. (1963). Preface to Plato. Oxford: Blackwell.

Hawkins, S. (2002). Settling the Pop Score: Pop Texts and Identity Politics. Aldershot, UK: Ashgate.

Hendy, D. (2000). Radio in the Global Age. Cambridge: Polity.

Hennion, A. (1997). Baroque and Rock: Music, Mediators, and Musical Taste. Poetics, 24, 415-435.

Hesmondhalgh, D., \& Negus, K. (Eds.). (2002). Popular Music Studies. London: Edward Arnold.

Hilmes, M., \& Loviglio, J. (Eds.). (2002). Radio Reader: Essays in the Cultural History of Radio. New York: Routledge.

Hodges, D. (Ed.). (1996). Handbook of Music Psychology. San Antonio, TX: IMR Press.

Howes, D. (Ed.). (1991). The Varieties of Sensory Experience: A Sourcebook in the Anthropology of the Senses. Toronto: University of Toronto Press.

Humphreys, L. (2005). Cellphones in Public: Social Interactions in a Wireless Area. New Media \& Society, 7(6), 810-833.

Hutchby, I. (2001). Conversation and Technology: From the Telephone to the Internet. Cambridge: Polity. Ihde, D. (1976). Listening and Voice: A Phenomenology of Sound. Athens, OH: Ohio University Press.

Innis, H. A. (1951). The Bias of Communication. Toronto: University of Toronto Press.

Innis, H. A. (1972). Empire and Communications. Toronto: University of Toronto Press. (Orig. publ. 1950).

James, J. (1995). The Music of the Spheres: Music, Science, and the Natural Order of the Universe. London: Abacus.

Jarviluoma, H. (Ed.). (1994). Soundscapes: Essays on Vroom and Moo. Tampere, Finland: Tampere University.

Jauss, H. R. (1982). Toward an Aesthetic of Reception. Brighton, UK: Harvester Press.

Jeffrey, P. (1992). Re-Envisioning Past Musical Cultures: Ethnomusicology in the Study of Gregorian Chant. Chicago: University of Chicago Press.

Jensen, K. B. (2002a). The humanities in media and communication research. In K. B. Jensen (Ed.), A Handbook of Media and Communication Research: Qualitative and Quantitative Methodologies. London: Routledge.

Jensen, K. B. (2002b). Introduction: The State of Convergence in Media and Communication Research. In K. B. Jensen (Ed.), A Handbook of Media and Communication Research: Qualitative and Quantitative Methodologies. London: Routledge. 
Jensen, K. B., \& Helles, R. (in press). The Silent Web: A Qualitative Analysis of Sound as Information and Communication in Websites. In M. Consalvo \& C. Haythornswaite (Eds.), Internet Research Annual (Vol. 4). Oxford: Berg.

Johnson, J. (2002). Who Needs Classical Music? Cultural Choice and Musical Value. Oxford: Oxford University Press.

Johnson, J. H. (1995). Listening in Paris: A Cultural History. Berkeley, CA: University of California Press.

Jones, S. G. (1992). Rock Formation: Music, Technology, and Mass Communication. Newbury Park, CA: Sage.

Jones, S. G. (Ed.). (1998). Cybersociety 2.0. Thousand Oaks, CA: Sage.

Jones, S. G. (Ed.). (2002). Pop Music and the Press. Philadelphia, PA: Temple University Press.

Juslin, P. N., \& Sloboda, J. (Eds.). (2001). Music and Emotion: Theory and Research. Oxford: Oxford University Press.

Kahn, D. (1999). Noise, Water, Meat: A History of Sound in the Arts. Cambridge, MA: MIT Press.

Kalinak, K. (1992). Settling the Score: Music and the Classical Hollywood Film. Madison, WI: University of Wisconsin Press.

Kassabian, A. (2001). Hearing Film: Tracking Identifications in Contemporary Hollywood Film Music. New York: Routledge.

Katz, J. E., \& Aakhus, M. (Eds.). (2002). Perpetual Contact: Mobile Communication, Private Talk, Public Performance. Cambridge: Cambridge University Press.

Katz, R. (1986). Divining the Powers of Music: Aesthetic Theory and the Origins of Opera. New York: Pendragon Press.

Kay, A., \& Goldberg, A. (1999). Personal Dynamic Media. In P. A. Mayer (Ed.), Computer Media and Communication: A Reader (pp. 111-119). Oxford: Oxford University Press. (Orig. publ. 1977).

Keil, C. (1966). Urban Blues. Chicago: Chicago University Press.

Kennedy, G. A. (1980). Classical Rhetoric and Its Christian and Secular Tradition from Ancient to Modern Times. Chapel Hill, NC: University of North Carolina Press.

Kerman, J. (1985). Contemplating Music: Challenges to Musicology. Cambridge, MA: Harvard University Press.

Kingsbury, H. (1988). Music, Talent, and Performance: A Conservatory Cultural System. Philadelphia, PA: Temple University Press.

Kozloff, S. (2000). Overhearing Film Dialogue. Berkeley, CA: University of California Press.

Kramer, L. (2002). Musical Meaning: Toward a Critical History. Berkeley, CA: University of California Press.

Labov, W. (1972). The Logic of Non-standard English. In P. P. Giglioli (Ed.), Language and Social Context. Harmondsworth, UK: Penguin. (Orig. publ. 1969).

Langer, S. K. (1957). Philosophy in a New Key: A Study in the Symbolism of Reason, Rite, and Art (3rd ed.). Cambridge, MA: Harvard University Press.

Lanza, J. (1994). Elevator Music: A Surreal History of Muzak, Easy-Listening, and Other Mood-Song. New York: Picador.

Leeuwen, T. v. (1999). Speech, Music, Sound. London: Macmillan.

Leppert, R. (1993). The Sight of Sound: Music, Representation, and the History of the Body. Berkeley, CA: University of California Press.

Lerdahl, F., \& Jackendoff, R. (1983). A Generative Theory of Tonal Music. Cambridge, MA: MIT Press.

Levy, M. (Ed.). (1993). Symposium: Virtual Reality: A Communication Perspective (Vol. 43(4)): Journal of Communication.

Leyshon, A., Webb, P., French, S., Thrift, N., \& Crewe, L. (2005). On the Reproduction of the Musical Economy after the Internet. Media, Culture \& Society, 27(2), 177-209.

Lievrouw, L., \& Livingstone, S. (Eds.). (2002). Handbook of New Media: Social Shaping and Social Consequences. London: Sage.

Ling, R. (2004). The Mobile Connection: The Cell Phone's Impact on Society. Amsterdam: Elsevier.

Longhurst, B. (1995). Popular Music and Society. Cambridge: Polity.

Lyytinen, K., \& Yoo, Y. (2002). Issues and Challenges in Ubiquitous Computing. Communications of the ACM, 45(12), 63-65.

Manuel, P. (1988). Popular Musics of the Non-Western World: An Introductory Survey. New York: Oxford University Press.

Martin, P. J. (1995). Sounds and Society: Themes in the Sociology of Music. Manchester: Manchester University Press.

Marx, L. (1964). The Machine in the Garden: Technology and the Pastoral Ideal in America. New York: Oxford University Press. 
McAdams, S., \& Bigand, E. (Eds.). (1993). Thinking in Sound: The Cognitive Psychology of Human Audition. Oxford: Clarendon Press.

McClary, S. (1991). Feminine Endings: Music, Gender, and Sexuality. Minneapolis: University of Minnesota Press.

McClary, S. (2000). Conventional Wisdom: The Content of Musical Form. Berkeley, CA: University of California Press.

McLuhan, M. (1964). Understanding Media. New York: McGraw-Hill.

McLuhan, M., \& Fiore, Q. (1967). The Medium is the Massage: An Inventory of Effects. Toronto: Bantham Books.

McQuail, D. (2005). McQuail's Mass Communication Theory (5th ed.). London: Sage.

Megarry, T. (1995). Society in Prehistory: The Origins of Human Culture. London: Macmillan.

Meyer, L. B. (1956). Emotion and Meaning in Music. Chicago: University of Chicago Press.

Meyrowitz, J. (1985). No Sense of Place: The Impact of Electronic Media on Social Behavior. New York: Oxford University Press.

Meyrowitz, J. (1994). Medium Theory. In D. Crowley \& D. Mitchell (Eds.), Communication Theory Today. Cambridge: Polity Press.

Middleton, R. (1990). Studying Popular Music. Milton Keynes, UK: Open University Press.

Middleton, R. (Ed.). (2002). Reading Pop: Approaches to Textual Analysis in Popular Music. Oxford: Oxford University Press.

Millard, A. (1995). America on Record: A History of Recorded Sound. Cambridge: Cambridge University Press.

Nattiez, J.-J. (1990). Music and Discourse: Toward a Semiology of Music. Princeton, NJ: Princeton University Press.

Negus, K. (1992). Producing Pop: Culture and Conflict in the Popular Music Industry. London: Edward Arnold.

Negus, K., \& Street, J. (2002). Introduction to 'Music and Television' Special Issue. Popular Music, 21(3), 245-248.

Nettl, B. (1992). Mozart and the Ethnomusicological Study of Western Culture: An Essay in Four Movements. In K. Bergeron \& P. V. Bohlman (Eds.), Disciplining Music: Musicology and Its Canons. Chicago: University of Chicago Press.

Nettl, B. (1995). Heartland Excursions: Ethnomusicological Reflections on Schools of Music. Urbana, IL: University of Illinois Press.

Nettl, B., \& Bohlman, P. V. (Eds.). (1991). Comparative Musicology and Anthropology of Music: Essays in the History of Ethnomusicology. Chicago: University of Chicago Press.

Nott, J. J. (2002). Music for the People: Popular Music and Dance in Interwar Britain. Oxford: Oxford University Press.

Nyre, L. (2003). Fidelity Matters: Sound Media and Realism in the Twentieth Century. Volda, Norway: Volda University College.

Olender, M. (1992). The Languages of Paradise: Race, Religion, and Philology in the Nineteenth Century. Cambridge, MA: Harvard University Press.

Ong, W. (1982). Orality and Literacy. London: Methuen.

Ostwald, P. F. (1973). The Semiotics of Human Sound. The Hague: Mouton.

Partridge, D. (1991). A New Guide to Artificial Intelligence. Norwood, NJ: Ablex.

Paul, C. (2003). Digital Art. London: Thames \& Hudson.

Perelman, C. (1979). The New Rhetoric and the Humanities. Dordrecht, The Netherlands: Reidel.

Peters, J. D. (1999). Speaking into the Air: A History of the Idea of Communication. Chicago: University of Chicago Press.

Peterson, R. A., \& Kern, R. M. (1996). Changing Highbrow Taste: From Snob to Omnivore. American Sociological Review, 61(5), 900-907.

Phillips, L., \& Winther Jørgensen, M. (2002). Discourse Analysis as Theory and Method. London: Sage.

Pittam, J. (1994). Voice in Social Interaction: An Interdisciplinary Approach. Thousand Oaks, CA: Sage.

Plomp, R. (2002). The Intelligent Ear: On the Nature of Sound Perception. Mahwah, NJ: Lawrence Erlbaum.

Posner, R., Robering, K., \& Sebeok, T. A. (Eds.). (1997-98). Semiotics: A Handbook of the Sign-Theoretic Foundations of Nature and Culture. Berlin: Walter de Gruyter.

Postman, N. (1985). Amusing Ourselves to Death. New York: Viking.

Potter, J. (1998). Vocal Authority: Singing Style and Ideology. Cambridge: Cambridge University Press.

Rogers, E. M. (1999). Anatomy of Two Subdisciplines of Communication Study. Human Communication Research, 25(4), 618-631. 
Roszak, T. (1969). The Making of a Counter Culture: Reflections on the Technocratic Society and Its Youthful Opposition. Garden City, NY: Doubleday.

Saussure, F. d. (1959). Course in General Linguistics. London: Peter Owen. (Orig. publ. 1916).

Scannell, P. (Ed.). (1991). Broadcast Talk. London: Sage.

Scannell, P., \& Cardiff, D. (1991). A Social History of British Broadcasting: 1922-1939 Serving the Nation (Vol. 1). Oxford: Blackwell.

Schafer, R. M. (1977). The Tuning of the World. New York: Alfred A. Knopf.

Schneider, S. K. (1994). Concert Song as Seen: Kinesthetic Aspects of Musical Interpretation. Stuyvesant, NY: Pendragon Press.

Schütz, A. (1976a). Fragments on the Phenomenology of Music. Music and Man, 2, 5-71. (Orig. publ. 1944).

Schütz, A. (1976b). Making Music Together: A Study in Social Relationship. In Collected Papers (Vol. 2). The Hague: Martinus Nijhoff. (Orig. publ. 1951).

Scott, D. B. (Ed.). (2000). Music, Culture, and Society: A Reader. Oxford: Oxford University Press.

Scribner, S., \& Cole, M. (1981). The Psychology of Literacy. Cambridge, MA: Harvard University Press.

Searle, J. R. (1969). Speech Acts. London: Cambridge University Press.

Shaw-Miller, S. (2002). Visible Deeds of Music: Art and Music from Wagner to Cage. New Haven, CT: Yale University Press.

Shuker, R. (2001). Understanding Popular Music. London: Routledge.

Simon, H. W. (Ed.). (1989). Rhetoric in the Human Sciences. London: Sage.

Sloboda, J. (1985). The Musical Mind: The Cognitive Psychology of Music. Oxford: Clarendon Press.

Small, C. (1987). Performance as Ritual: Sketch for an Enquiry into the True Nature of a Symphony Concert. In A. L. White (Ed.), Lost in Music: Culture, Style, and the Musical Event. London: Routledge \& Kegan Paul.

Smith, B. R. (1999). The Acoustic World of Early Modern England: Attending to the O-Factor. Chicago: University of Chicago Press.

Smith, M. M. (2001). Listening to Nineteenth-Century America. Chapel Hill, NC: University of North Carolina Press.

Solie, R. A. (Ed.). (1991). Musicology and Difference: Gender and Sexuality in Music Scholarship. Berkeley, CA: University of California Press.

Southworth, M. (1969). The Sonic Environment of Cities. Environment and Behavior, 1(1), 49-70.

Stacey, J. (1994). Star Gazing: Hollywood Cinema and Female Spectatorship. London: Routledge.

Stam, R., Burgoyne, R., \& Flitterman-Lewis, S. (1992). New Vocabularies in Film Semiotics. London: Routledge.

Starr, L., \& Waterman, C. (2003). American Popular Music: From Minstrelsy to MTV. New York: Oxford University Press.

Sterne, J. (2003). The Audible Past: Cultural Origins of Sound Reproduction. Durham, NC: Duke University Press.

Stockburger, A. (2003). The Game Environment from an Auditory Perspective. Paper presented at the Level Up: Digital Games Research Conference, Utrecht.

Subotnik, R. R. (1991). Developing Variations: Style and Ideology in Western Music. Minneapolis: University of Minnesota Press.

Tagg, P. (1979). Kojak. 50 Seconds of Television Music: Towards the Analysis of Affect in Popular Music. Gothenburg, Sweden: University of Gothenburg.

Tagg, P., \& Clarida, B. (2003). Ten Little Title Tunes: Towards a Musicology of the Mass Media. New York: The Mass Media Music Scholars' Press.

Tarasti, E. (1994). A Theory of Musical Semiotics. Bloomington, IN: Indiana University Press.

Thompson, E. (2002). The Soundscape of Modernity: Architectural Acoustics and the Culture of Listening in America. Cambridge, MA: MIT Press.

Thompson, E. P. (1991). Customs in Common. London: Merlin.

Toop, D. (1995). Ocean of Sound: Aether Talk, Ambient Sound, and Imaginary Worlds. London: Serpent's Tail.

Treitler, L. (Ed.). (1998). Strunk's Source Readings in Music History (Revised ed.). New York: Norton.

Truax, B. (1995). Sound in Context: Acoustic Communication and Soundscape Research at Simon Fraser University. Retrieved January 15, 2004, from http://interact.uoregon.edu/MediaLit/WFAE/readings/ Truaxcontext.html

Truax, B. (2001). Acoustic Communication (2nd ed.). Westport, CT: Ablex.

Watzlawick, P., Beavin, J. H., \& Jackson, D. D. (1967). Pragmatics of Human Communication: A Study of Interactional Patterns, Pathologies, and Paradoxes. New York: Norton. 
Weber, M. (1958). The Rational and Social Foundations of Music. New York: Southern Illinois University Press. (Orig. publ. 1921).

Wegman, R. C. (Ed.). (1998). Special Issue: Music as Heard (Vol. 82(3-4)): The Musical Quarterly.

Wetherell, M., Taylor, S., \& Yates, S. (Eds.). (2001). Discourse Theory and Practice: A Reader. London: Sage.

White, A. L. (Ed.). (1987). Lost in Music: Culture, Style, and the Musical Event. London: Routledge \& Kegan Paul.

Whiteley, S., Bennett, A., \& Hawkins, S. (Eds.). (2004). Music, Space, and Place: Popular Music and Cultural Identity. Aldershot, UK: Ashgate.

Wigram, T., Saperston, B., \& West, R. (Eds.). (1995). The Art and Science of Music Therapy: A Handbook. Chur, Switzerland: Harwood.

Williams, D., Caplan, S., \& Xiong, L. (2005). Can You Hear Me Now? The Impact of Voice in Online Communities. Paper presented at the Internet Research 6.0 Conference, Chicago, USA.

Wittgenstein, L. (1958). Philosophical Investigations. London: Macmillan. 